\title{
"EXPERIMENTAL AND NUMERICAL INVESTIGATIONS ON THE SEISMIC BEHAVIOUR OF THE SAN FREDIANO BELL TOWER IN LUCCA,
}

\author{
Riccardo Mario Azzara ${ }^{1}$, Maria Girardi ${ }^{*}, 2$, Cristina Padovani², Daniele Pellegrini ${ }^{2}$ \\ (1) INGV Istituto Nazionale di Geofisica e Vulcanologia, Osservatorio Sismologico di Arezzo, Italy \\ (2) ISTI-CNR Institute of Information Science and Technologies “A. Faedo", Pisa, Italy
}

Article history

Receveid November 16, 2018; accepted February 11, 2019.

Subject classification:

seismic monitoring, operational modal analysis, nonlinear dynamics, finite element modelling, masonry towers.

\begin{abstract}
This paper presents a study on the seismic response of the San Frediano bell tower in Lucca. The tower's ambient vibrations were continuously monitored for about one year, from October 2015 to October 2016. During this monitoring campaign, many seismic events were recorded on the tower and the most relevant turned out to be the Amatrice earthquake, which struck Central Italy on 24 August 2016. The paper begins with a review of the experimental results obtained. Then, a finite element numerical model of the tower is presented and validated via model updating, by assuming the tower's constituent materials to be unable to withstand tensile stresses. The experimental records of the Amatrice earthquake are also included in the analysis to assess the dynamic behaviour of the finite element model under ambient vibrations. Finally, a numerical simulation is performed of the tower subjected to the Lunigiana earthquake, recorded in Fivizzano (Tuscany) on 21 June 2013: the results of the dynamic analysis are presented and discussed.
\end{abstract}

\section{INTRODUCTION}

Ancient masonry towers, which constitute an important part of the Italian architectural heritage, generally exhibit high sensitivity to dynamic actions, such as ambient vibrations, bell swinging, etc. For this reason, continuous long-term vibration monitoring represents an effective non-destructive technique to investigate and check the dynamic behaviour and the health status of such structures [Azzara et al., 2014]. In fact, changes in their modal properties (natural frequencies, mode shapes and damping ratios) can represent effective damage indicators, as described in [Gentile and Saisi, 2007; Masciotta et al., 2017; Ubertini et al., 2018; Azzara et al., 2018]. Moreover, the structural scheme of masonry towers is generally simple, and the use of finite element (FE) model updating techniques allows obtaining useful information on the boundary conditions and mechanical properties of their constituent materials [Júlio et al., 2008; D’Ambrisi et 
al., 2012; Bartoli et al., 2013; Sabia et al., 2015; De Stefano et al., 2016; Ferraioli et al., 2017; de Silva et al., 2018], even in the presence of structural damage [Pineda et al., 2011; Zanotti Fragonara et al., 2017; Pellegrini et al., 2018].

The literature contains many contributions regarding the seismic vulnerability of age-old masonry towers, underscoring the importance of the issue. Moreover, recent seismic events in Northern and Central Italy, such as the Emilia earthquake (2012) and the Amatrice earthquake (2016) involved many historic masonry towers and pose important questions on the assessment of such structures under seismic actions.

In light of the Italian [D.M. 2018; D.P.C.M. 2011] and international regulations, the most often used methodology in the literature relies on the use of equivalent static actions and pushover analyses. In Bernardeschi et al., [2004] the seismic load is modeled via static equivalent loads and a nonlinear analysis is performed, by using the constitutive equation of masonry-like materials [Lucchesi et al., 1994] in order to reproduce the actual crack pattern in the structure. With regard to the application of pushover analysis for the seismic assessment of masonry towers, some recent studies provide high detailed discussion of the methodology used [Resta et al., 2013; Cattari et al., 2014; Preciado, 2015; Valente and Milani, 2016b; Cakir et al., 2016; Bocciarelli and Barbieri, 2017; Bartoli et al., 2017; Shayka et al., 2018].

The seismic vulnerability of masonry towers has also been investigated via fully dynamic analysis [Clough and Penzien, 1975], which consists in the numerical integration of the equations of motion resulting from FE discretisation of the construction subjected to artificial or real time-histories of acceleration/velocity/displacement. The choice of the constitutive equation to realistically model the mechanical behaviour of the towers is of crucial importance: in fact, because of masonry's inability to withstand tensile stresses and large compressive stresses, ancient towers may exhibit damage due to the only permanent loads. This nonlinear behaviour strongly influences the towers' response to dynamic actions, which linear elastic constitutive laws are unable to predict.

Some first attempts to study the dynamic behaviour of masonry towers through numerical tools are shown in [Casolo, 1998; Lucchesi and Pintucchi, 2007], where numerical procedures have been implemented by using one-dimensional finite elements and $a d$ - hoc constitutive laws. In Callieri et al., [2010] the mechanical behaviour of the San Gimignano "Rognosa" tower subjected to a natural accelerogram is studied via the masonry-like constitutive equation. Lourenço et al., [2009] shows an application to a minaret in India, and Bayaktar et al. [2010] presents a nonlinear dynamic analysis of the Haghia Sophia bell tower in Trabzon, Turkey. Both these applications rely on the use of nonlinear constitutive laws implemented whitin commercial codes. More recently, numerous papers have been devoted to investigating the dynamic behaviour of masonry towers under seismic loads with particular regard to northern Italy [Milani et al., 2012; Casolo and al., 2013; Acito et al., 2014; Minghini et al., 2014; Valente et al., 2016a; Castellazzi et al., 2018; D’Altri et al., 2018; Karanikoloudis et al., 2018]: these papers focus on the comparison of the results obtained via fully dynamic and pushover analyses.

This paper presents the experimental and numerical investigations performed on the dynamic behaviour of the San Frediano bell tower, located in the historic centre of Lucca (Italy).

The ambient vibrations of the tower, instrumented with four tri-axial seismometric stations, have been continuously monitored from 28 0ctober 2015 to 16 October 2016. The accuracy of the measurement devices and the availability of powerful system identification algorithms allowed a great deal of information to be collected on both the tower's dynamic behaviour and its dependence on environmental parameters, such as temperature [Azzara et al. 2018]. On 24 August 2016, at 01:36 a.m. (UTC), the signal of the Mw 6.0 Amatrice earthquake was detected and recorded on the tower. Although the epicentral distance is about $400 \mathrm{~km}$ from Lucca, the earthquake signal was clearly revealed by the sensors, with velocities at the tower's top on the same order of magnitude as those induced by the swinging of the bells. The results of the monitoring campaign, with particular focus on the signals from the seismic event recorded on the tower, are reported in Section 2.

Section 3 is instead devoted to the numerical modelling of the tower's dynamic behaviour. Briefly, the modelling procedure is as follows. The mechanical properties of the tower's constituent materials are first obtained via FE model updating: in particular, a numerical procedure, based on linear perturbation and modal analysis, is adopted, which allows taking into account the effects of masonry's weak tensile strength on the modal properties of the structure [Girardi et al., 2018].

Then a FE numerical simulation is performed by assigning to the tower model the signal of the Amatrice earthquake recorded at the base of the structure: the experimental and numerical results are compared. 
Lastly, the tower model is subjected to the accelerogram recorded in Fivizzano on 21 June 2013 at 10:33 a.m. (UTC), during the Mw 5.1 Lunigiana earthquake. Fivizzano is about $50 \mathrm{~km}$ from Lucca, and the Peak Ground Acceleration (PGA) of the event was $1.38 \mathrm{~m} / \mathrm{s}^{2}$. The effects of the accelerogram on the tower are then addressed.

The FE model updating and dynamic analysis are performed via the NOSA-ITACA code [Binante et al. 2017; Degl'Innocenti et al., 2006; Padovani et al., 2008], a FE software implemented by the Mechanics of Materials and Structures laboratory of ISTI-CNR, to which the authors belong. The software has been specifically developed for the structural analysis of ancient masonry constructions.

The novelty of the paper relies on the twofold exploitation of the experimental data recorded on the tower. On the one hand, they are used to conduct a nonlinear model updating, on the other, they are compared with the numerical results of the updated FE model subjected to the Amatrice earthquake recorded in Lucca. In this way, the experimental results turn out to be useful not only to build a realistic FE model of the tower, but also for validating the numerical method implemented in NOSA-ITACA, with particular regard to the tower's response to ambient vibrations.

\section{THE EXPERIMENTAL CAMPAIGN AND THE AMATRICE EARTHQUAKE}

The Basilica of San Frediano (see Figure 1) dates back to the $11^{\text {th }}$ century and the church's bell tower (Figure 2) is one of the best preserved in the Lucca's historic centre. The geometry of the tower is illustrated in Figure 3. It is $52 \mathrm{~m}$ high, with walls varying in thickness from about $2.1 \mathrm{~m}$ at the base to $1.6 \mathrm{~m}$ at the top. The tower is entered through a masonry staircase leading from the street level to the first floor, which is formed by a masonry vault set at a height of about 8.6 $\mathrm{m}$. From this level, a stone staircase running along the inner perimeter provides access to the terminal section of the tower, at a height of about $40 \mathrm{~m}$, which houses the bells (Figure 4). The bell chamber is separated from the rest of the structure by a stiff masonry vault, reinforced with 4 rectangular cross section steel tie rods. At about $43 \mathrm{~m}$, a walkable wooden floor overlies the vault and serves to allow access to the bells. The tower's walls have openings, in various ornate windows, on all sides. It is covered by a pavilion roof made up of wooden trusses and rafters in a very poor state of maintenance.

No rigid diaphragms are present inside the tower between the two vaults. The San Frediano Basilica adjoins the tower on two sides for about $13 \mathrm{~m}$ of its height.

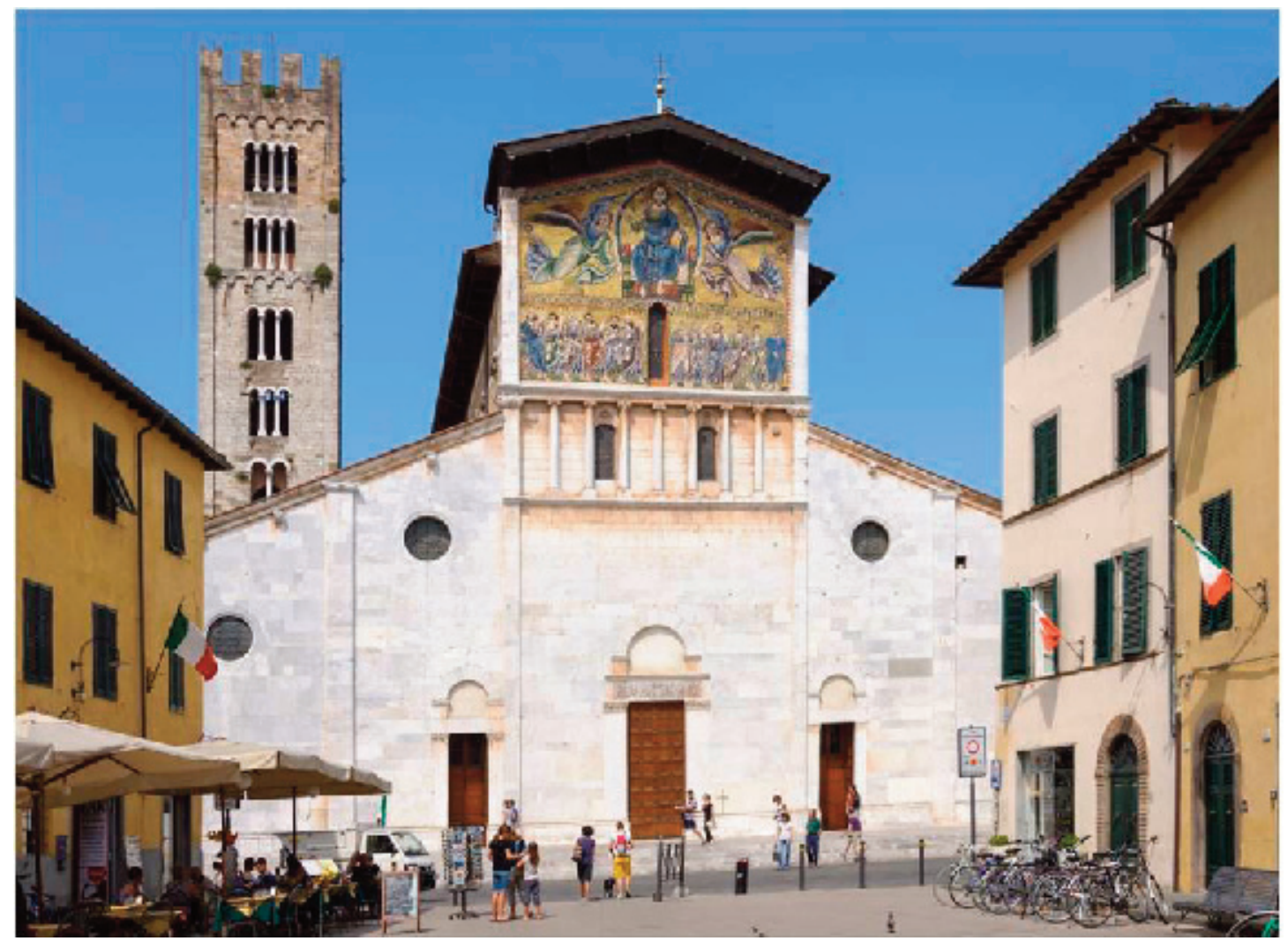

FIGURE 1. The Basilica of San Frediano in Lucca and its bell tower. 


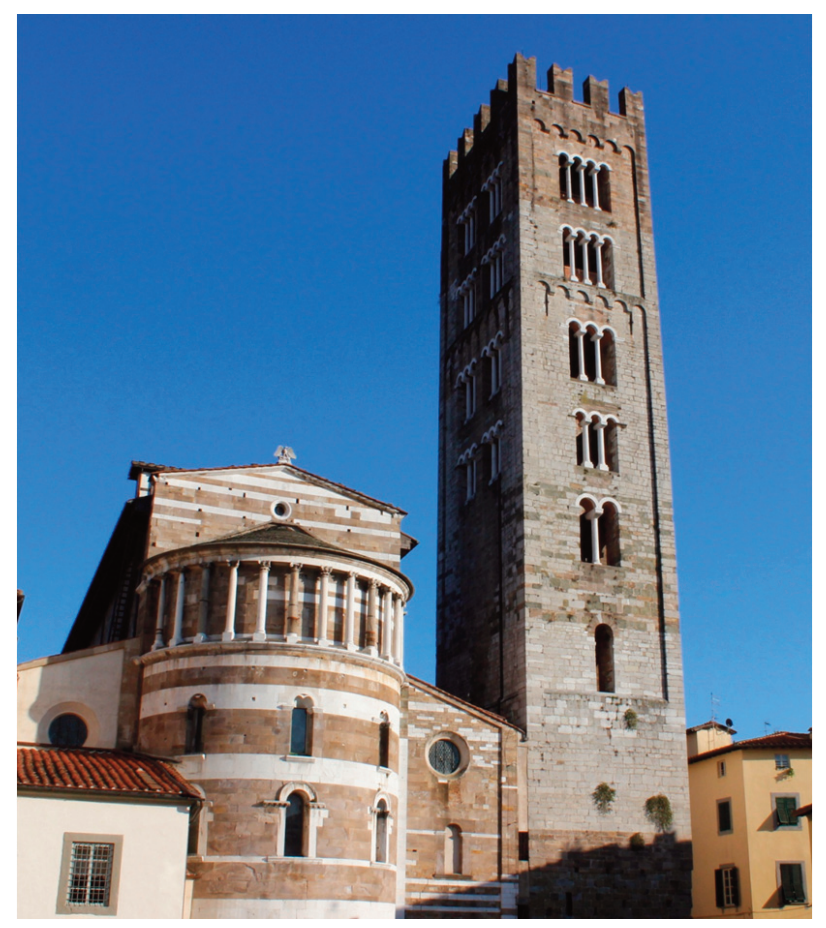

FIGURE 2. The San Frediano bell tower.

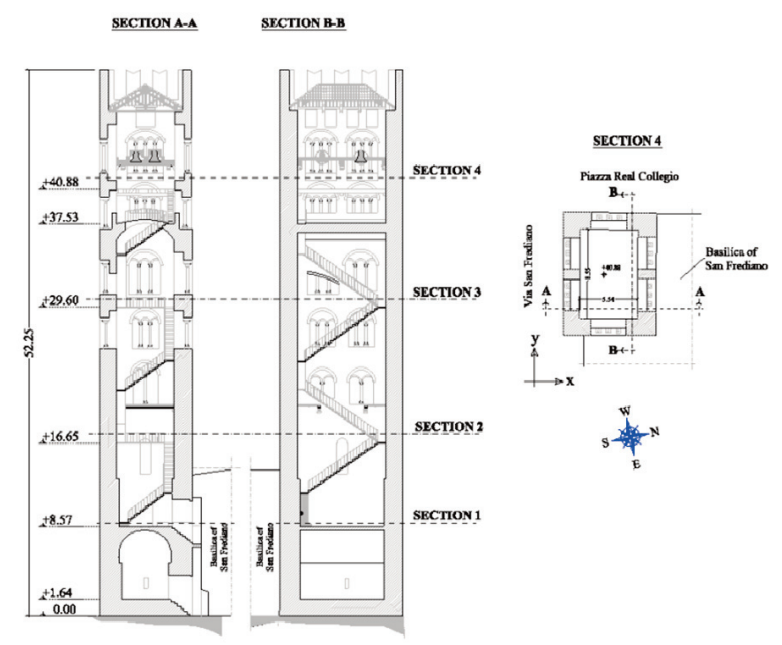

FIGURE 3. Geometry of the San Frediano bell tower.

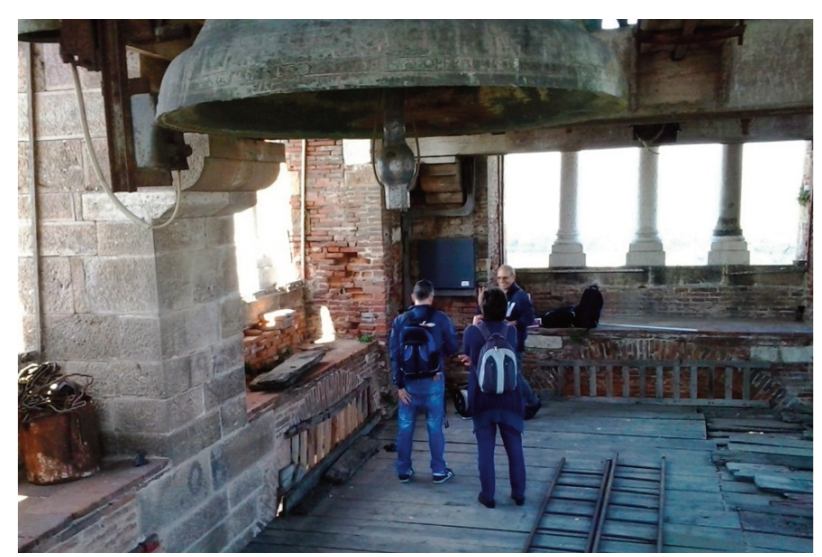

FIGURE 4. The San Frediano bell chamber.

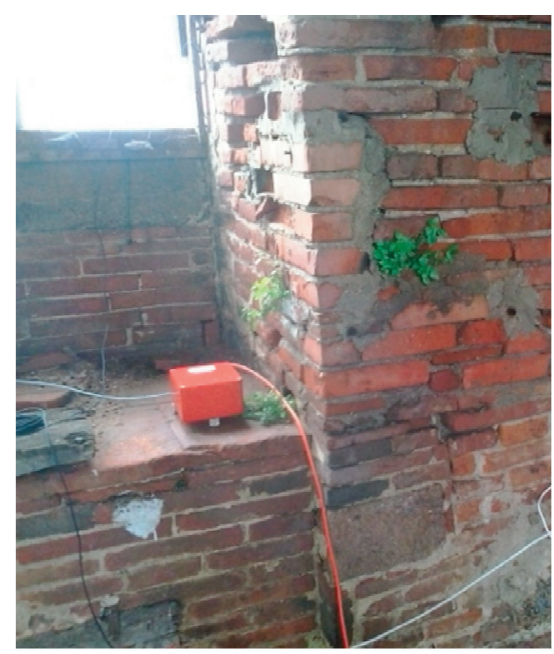

FIGURE 5. A SARA seismic station installed on the bell chamber.

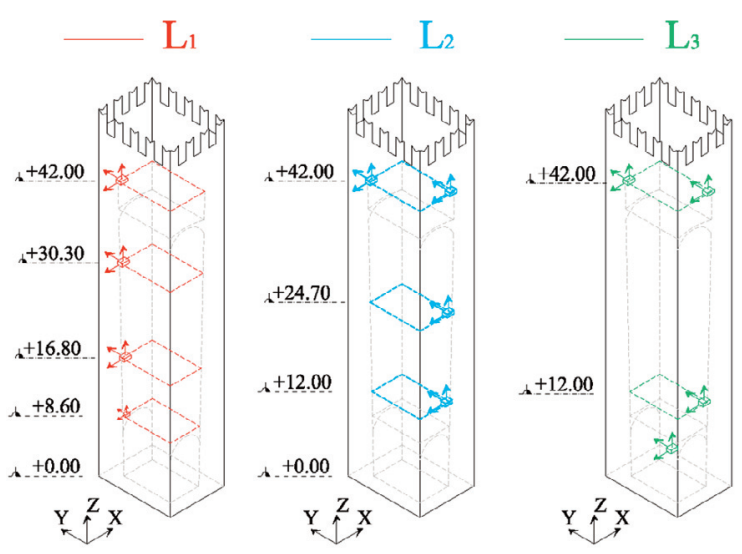

FIGURE 6. Sensor layouts during the monitoring period. Layout 1 (L1): from 28 May 2015 to 3 June 2015. Layout 2 (L2): from 28 October 2015 to 27 May 2016. Layout 3 (L3): from 27 May 2016 to 16 October 2016.

With regard to the tower's constituent materials, on visual inspection, the masonry appears to be made of regular stone blocks at the base, while quite homogeneous brick masonry is visible in the upper section, apart from the central part of the walls, where the masonry between the windows is made up of stone blocks.

Between May and June 2015, the tower was instrumented with four SARA (www.sara.pg.it) tri-axial seismometric stations (Figure 5). Each station was equipped with a SL06 24-bit digitizer coupled to a SS20 seismometer (electrodynamic velocity transducer, $2.0 \mathrm{~Hz}$ eigenfrequency), made available by the Arezzo Seismology Observatory (INGV). The instruments were arranged on the San Frediano bell tower along a vertical line, as shown in layout L1 of Figure 6, and left active on the tower for five days. The results of this experiment are reported in [Azzara et al. 2016; Barsoc- 
chi et al., 2018]. Subsequently, the instruments were installed again on the tower and left active from 28 0ctober 2015 to 16 October 2016 [Azzara et al. 2018]. Over

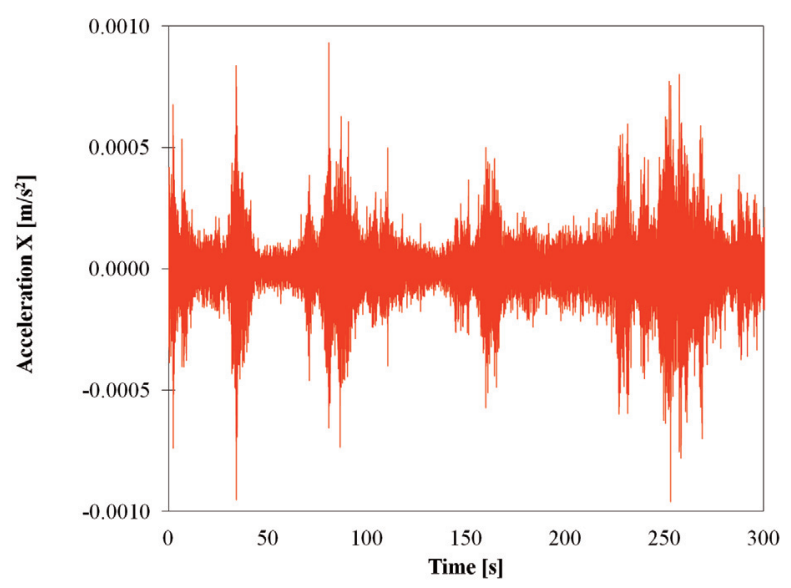

FIGURE 7. Acceleration in the $\mathrm{X}$ direction recorded by a sensor on the bell chamber (+42 m), 1 August, 2016 at 11:00 UTC.

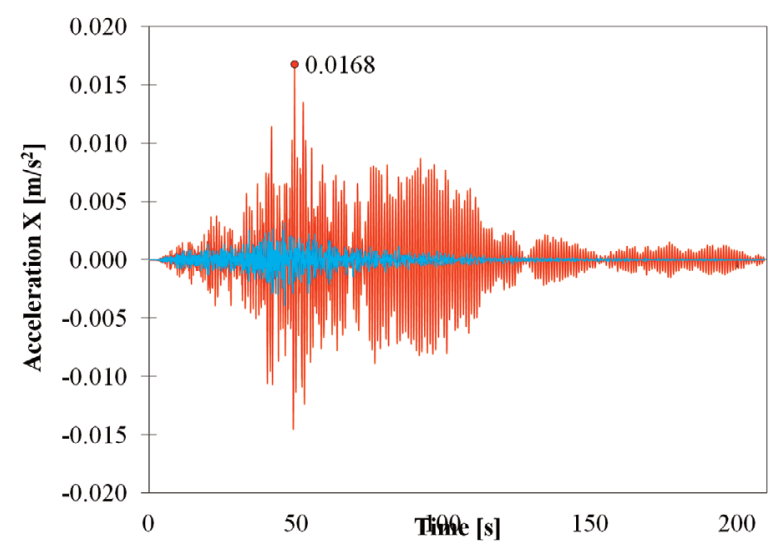

FIGURE 8. Amatrice earthquake. Acceleration in X direction at the base (cyan) and at the level of the bell chamber (red).

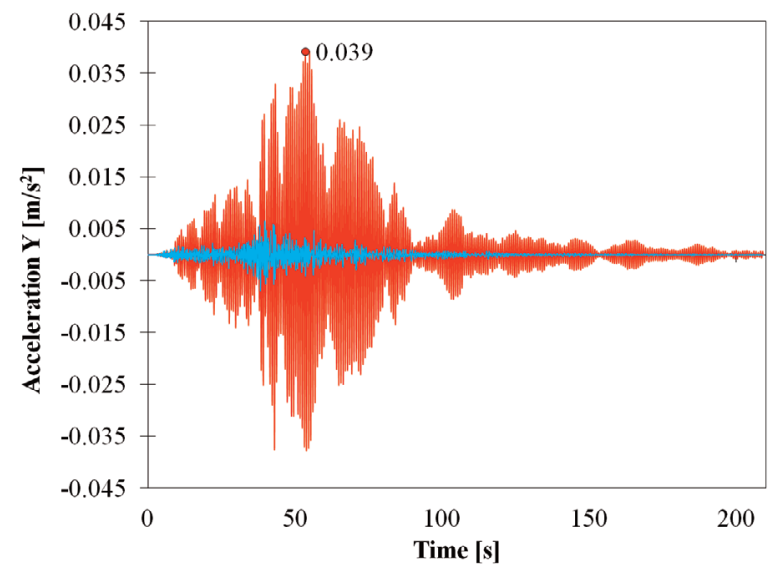

FIGURE 9. Amatrice earthquake. Acceleration in the Y direction at the base (cyan) and at the level of the bell chamber (red). the course of this year, two main sensor layouts were chosen. In the first (reported as L2 in Figure 6), two sensors were placed on two opposite sides of the bell chamber, and the remaining aligned along the tower. In the second (reported as L3 in Figure 6), one of the sensors along the tower's height was moved to the base, in order to measure ground vibrations. It was in this layout that the Amatrice seismic sequence was recorded on 24 August 2016. In all the experiments the sampling frequency was set to $100 \mathrm{~Hz}$. Data from the sensors have been analysed via the MACEC code [Reynders et al., 2014], in which the Covariance Driven Stochastic Subspace Identification method (SSI/Cov) [Brincker and Ventura, 2015; Reynders et al., 2016], amongst others, is implemented. The data have been split into different records, each one hour long, and analyzed separately. The parameters used in the analyses are: the number of block rows in the correlation matrix, set to 100 , and the number of data blocks for evaluating the variance of the output correlation estimates, set to 200. Table 1 reports the mean values, evaluated in August 2016, of the first five frequencies identified and their corresponding damping ratios. The first two frequencies correspond to flexural mode shapes, the first along the $\mathrm{X}$ direction and the second along Y. The third frequency appears along both the $\mathrm{X}$ and $\mathrm{Y}$ directions: it likely relates to a torsional mode shape. The last two frequencies correspond once again to flexural model shapes. More details on mode shapes are given in [Azzara et al. 2018].

Figure 7 shows the plot of a typical time history of the accelerations recorded on the tower: the acceleration level is very low, on the order of $5 \cdot 10^{-4} \mathrm{~m} / \mathrm{s}^{2}$. However, important variations in the acceleration levels were observed during the study period, with peaks of up to $3 \cdot 10^{-2} \mathrm{~m} / \mathrm{s}^{2}$, corresponding to the swinging of the

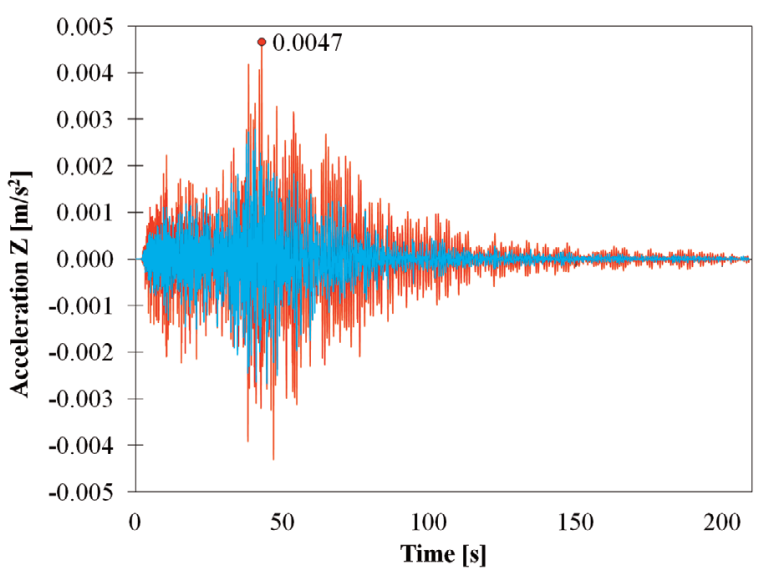

FIGURE 10. Amatrice earthquake. Acceleration in the $\mathrm{Z}$ direction at the base (cyan) and at the level of the bell chamber (red). 
bells and the more trafficked hours of the day, as well as to the Amatrice earthquake.

On 24 August 2016, at 1:36 a.m. (UTC), the seismic sequence from the Amatrice earthquake, which hit central Italy with Mw 6.0 and PGA of $8.5 \mathrm{~m} / \mathrm{s}^{2}$ (recorded at the Amatrice site), was also recorded on the tower. Although Lucca is about $400 \mathrm{~km}$ from Amatrice, the earthquake signal was clearly detected by the sensors, with velocities on the same order of magnitude as those induced by the swinging of the bells. No significant damage was observed on the tower.

Figures 8 to 10 report the $\mathrm{X}, \mathrm{Y}$ and $\mathrm{Z}$ accelerations recorded at the base (cyan) and at the top (red) of the bell tower on 24 August 2016, at the time of the Amatrice earthquake. Strong amplification of the signal along the tower's height can be observed, particularly in the horizontal directions, along which the signal at the top of the tower is more than 5 times that recorded at the base.

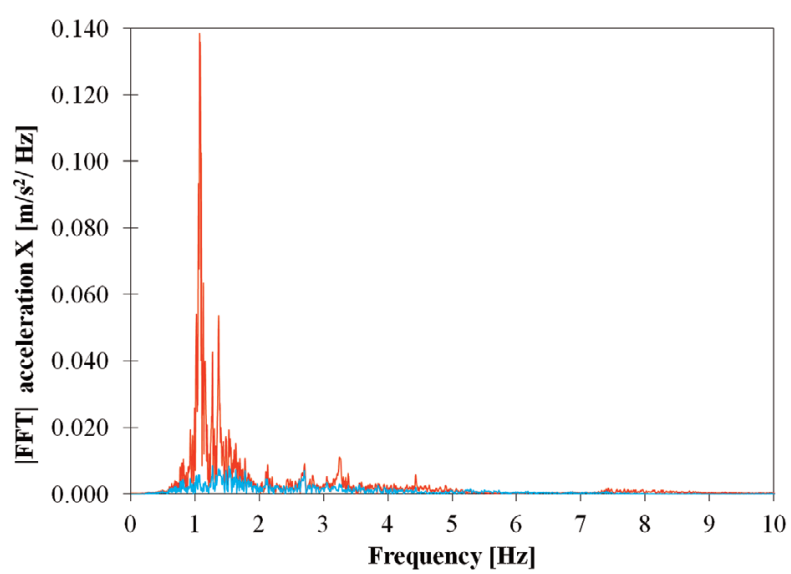

FIGURE 11. Amatrice earthquake. FFT of the acceleration in the $\mathrm{X}$ direction at the base (cyan) and at the level of the bell chamber (red).

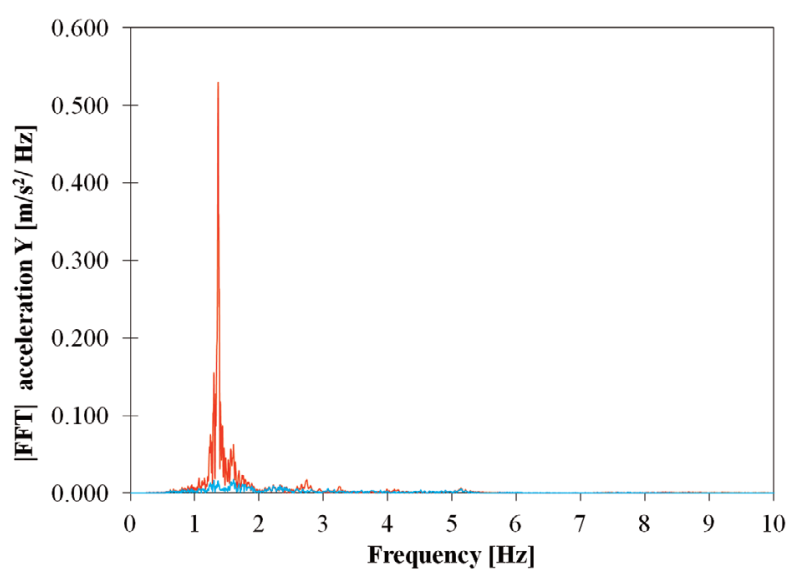

FIGURE 12. Amatrice earthquake. FFT of the acceleration in the Y direction at the base (cyan) and at the level of the bell chamber (red).

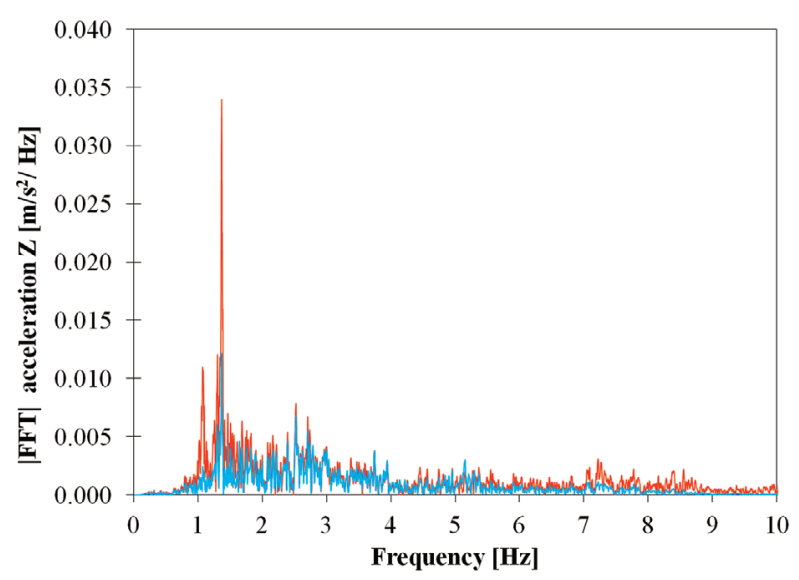

FIGURE 13. Amatrice earthquake. FFT of the acceleration in the $\mathrm{Z}$ direction at the base (cyan) and at the level of the bell chamber (red).

The maximum ground acceleration recorded at the base of the tower is on the order of $5 \cdot 10^{-3} \mathrm{~m} / \mathrm{s}^{2}$, while the maximum value recorded at the top is $3.9 \cdot 10^{-2} \mathrm{~m} / \mathrm{s}^{2}$. The Fast Fourier Transforms (FFT) of the accelerations at the base and the top are shown in the Figures 11, 12 and 13. The tower's natural frequencies, reported in Table 1, are highlighted by the earthquake and can be clearly identified in the figures. No significant changes in the tower's natural frequencies and in its damping ratios were found after the seismic event [Azzara et al., 2018].

\section{Frequency $[\mathrm{Hz}] \quad$ Damping $[\%]$}

$\begin{array}{lcc}\text { Mode } 1 \text { (Bending X) } & 1.11 & 1.40 \\ \text { Mode 2 (Bending Y) } & 1.39 & 1.22 \\ \text { Mode } 3 \text { (Torsional) } & 3.45 & 0.66 \\ \text { Mode 4 (Bending X) } & 4.64 & 4.01 \\ \text { Mode 5 (Bending Y) } & 5.37 & 5.13\end{array}$

TABLE 1. Mean August values of the vibration frequencies and damping ratios calculated via the Stochastic Subspace Identification method.

\subsection{NUMERICAL MODELLING OF THE TOWER'S DY- NAMIC BEHAVIOUR}

A widely adopted constitutive equation which describes the mechanical behaviour of masonry materials models them as nonlinear elastic materials with low tensile strength $\sigma_{t}>0$ and finite compressive strength $\sigma_{c}<0$ [Lucchesi et al., 2008]. This constitutive equation is able to take into account some of ma- 
sonry's peculiarities, in particular its inability to withstand large tensile stresses. Assumptions underlying the model are that the infinitesimal strain tensor $\mathbf{E}$ is the sum of an elastic part $\mathbf{E}^{e}$, a fracture part $\mathbf{E}^{f}$ and a crushing part $\mathbf{E}^{c}$, and that the stress tensor $\mathbf{T}$, whose eigenvalues belong to the interval $\left[\sigma_{c} \sigma_{t}\right]$, depends linearly and isotropically on the elastic part. The fracture strain and the crushing strain are respectively positive-semidefinite and negative- semidefinite and satisfy suitable orthogonality conditions involving the stress, which turns out to be a nonlinear function of the infinitesimal strain.

This constitutive equation generalizes the equation of masonry-like or no-tension materials described in Del Piero, [1989] and Di Pasquale, [1992] and has been implemented within the non-commercial FE software NOSA-ITACA [Girardi et al. 2015; Binante et al., 2017] developed and freely distributed by ISTI-CNR (www.nosaitaca.it). NOSA-ITACA, aimed at the static and dynamic analysis of masonry buildings, is the result of the integration of the FE code NOSA into the open-source SALOME platform (http://salome-platform.org). NOSA-ITACA moreover provides for the modal analysis of linear elastic [Porcelli et al., 2015] and masonry [Girardi et al., 2018] structures.

This section is devoted to the numerical modeling of the bell tower's dynamic behaviour. All numerical analyses presented in this paper have been conducted via the NOSA-ITACA code, already employed for dynamic analyses of the "Rognosa" tower [Callieri et al., 2010] and the Maddalena bridge in the Lucca territory [De Falco et al., 2014].

The San Frediano bell tower has been discretised into 18,645 thick shell and beam elements (element $\mathrm{n}$. 10 and 9 in Binante et al., [2017] with 113,538 degrees of freedom, as shown in Figure 14. Beams have been used to model the steel tie rods and wooden elements of the roof. Using shell elements made up of layers with different thicknesses and materials allows a detailed modelling of the walls geometry and, at the same time, reduces the computational cost of the dynamic analysis.

The masonry has been modelled as a homogeneous material with Poisson's ratio $v=0.2$, mass density $\rho=2000 \mathrm{~kg} / \mathrm{m}^{3}$, and compressive strength $\sigma_{c}$ $=-1.23 \mathrm{MPa}$. Young's modulus $E$ and the tensile strength $\sigma_{t}$ are unknown and can be determined via the model updating procedure adopted in [Pellegrini et al., 2018]. The structure is assumed to be clamped at its base, and additional fixed restraints have been imposed $12.50 \mathrm{~m}$ above the base to take into account for the church's adjacent walls.

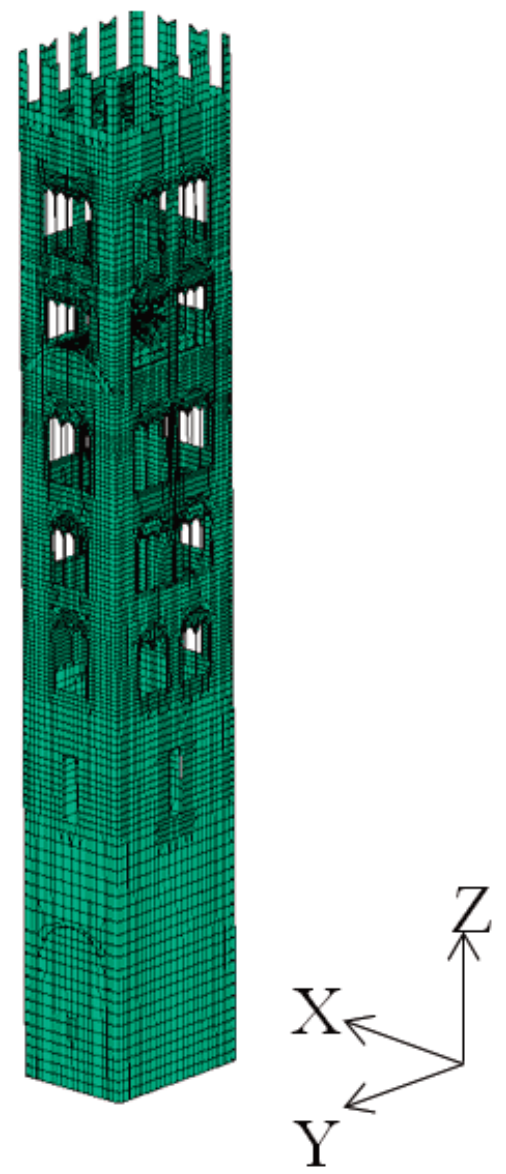

FIGURE 14. FE model of the San Frediano bell tower constructed via the NOSA-ITACA code.

\subsection{FINITE ELEMENT MODEL UPDATING}

FE model updating combines FE analysis and structural health monitoring, in order to obtain information on the boundary conditions and the mechanical properties of the structure's constituent materials. FE model updating consists of fine-tuning some of the model parameters in order to minimize the distance between the numerical and experimental modal properties (natural frequencies and mode shapes).

Girardi et al., [2018] describes the numerical procedure implemented in NOSA-ITACA: it is based on linear perturbation and allows evaluating the natural frequencies and mode shapes of masonry buildings in the presence of cracks, thereby taking into account masonry's nonlinear behaviour. The procedure consists of the following steps: (1) the initial loads and boundary conditions are applied to the FE model and the resulting nonlinear equilibrium problem is solved through an iterative scheme. (2) a modal analysis about the equilibrium solution is performed, using the tangent stiffness matrix calculated in the last iteration before convergence is reached, thereby allowing to automatically take into account the effects of the stress distri- 
bution on the structure's stiffness. Within this framework, a model updating procedure aimed at matching the experimental and numerical frequencies (calculated after a perturbation analysis), allows for assessing the unknown parameters, such as the mechanical properties and boundary conditions. In the case of the San Frediano bell tower, the global Young's modulus $E$ and tensile strength $\sigma_{t}$ of the masonry, considered to be homogeneous in the model, have been updated in order to fit the tower's experimental frequencies. Table 2 reports the values calculated via the model updating procedure in bold type (the mechanical properties of the wooden and steel elements respectively making up the roof and tie elements are also reported and taken as fixed during model updating). Table 3 instead shows a comparison between the numerical and experimental values of the tower's first four natural frequencies. The numerical procedure fits the first three mode shapes very well, while the fourth frequency, involving the higher order flexural mode shape along the $\mathrm{X}$ direction, is underestimated. The MAC (Modal assurance Criterion) between the numerical and experimental mode shapes is always over 0.9 .

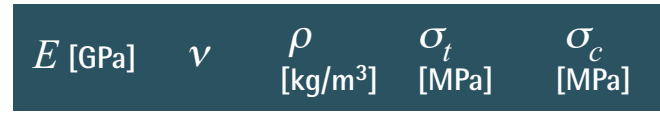

$\begin{array}{lccccc}\text { Masonry } & 4.25 & 0.2 & 2000 & 0.04 & -1.23 \\ \text { Wood } & 9.5 & 0.4 & 850 & - & - \\ \text { Iron } & 210 & 0.3 & 7850 & - & -\end{array}$

TABLE 2. FE model of the San Frediano bell tower: the constituent materials' mechanical properties. The results of the model updating procedure are in bold.

\begin{tabular}{cccc} 
& $f_{\text {exp }}[\mathrm{Hz}]$ & $f_{\text {num }}[\mathrm{Hz}]$ & $\Delta f[\%]$ \\
Mode 1 & 1.11 & 1.11 & 0.00 \\
Mode 2 & 1.39 & 1.38 & 0.72 \\
Mode 3 & 3.45 & 3.51 & -1.74 \\
Mode 4 & 4.64 & 4.25 & 8.41 \\
\hline
\end{tabular}

TABLE 3. Comparison between the tower's first four natural frequencies and those calculated via the updated FE model.

\subsection{NUMERICAL DYNAMIC ANALYSIS: RECORD OF THE AMATRICE EARTHQUAKE AT THE TOWER BASE}

The numerical model calibrated via the procedure described in the previous subsection has been subjected to accelerograms of different magnitude, in order to test the dynamic response of the tower to different excitation levels. The first test was conducted by using the accelerogram recorded by the authors at the base of the tower on 24 August 2016, corresponding to the 1:36 a.m. (UTC) Amatrice seismic sequence. After the dead loads were assigned, the seismic signal was applied to the model, whose numerical response to the dynamic excitation was then compared to that actually recorded on the tower. This provided a check of the numerical method implemented in NOSA-ITACA. The damping matrix adopted in the dynamic analysis has been calculated according to the Rayleigh hypothesis [Clough and Penzien, 1975], using the experimental damping ratios measured on the tower for the first two mode shapes reported in Table 1, after averaging on the August 2016 records. The duration of the quaking was $200 \mathrm{~s}$, and the time step for numerical integration was $0.04 \mathrm{~s}$. Figure 15 shows the response of the top of the tower (at the level of the bell chamber, about $+42 \mathrm{~m}$ ) in the X direction vs. time recorded by the instrument (red), together with that calculated by NOSA-ITACA (black). Figure 16 shows a plot of the numerical values of the acceleration
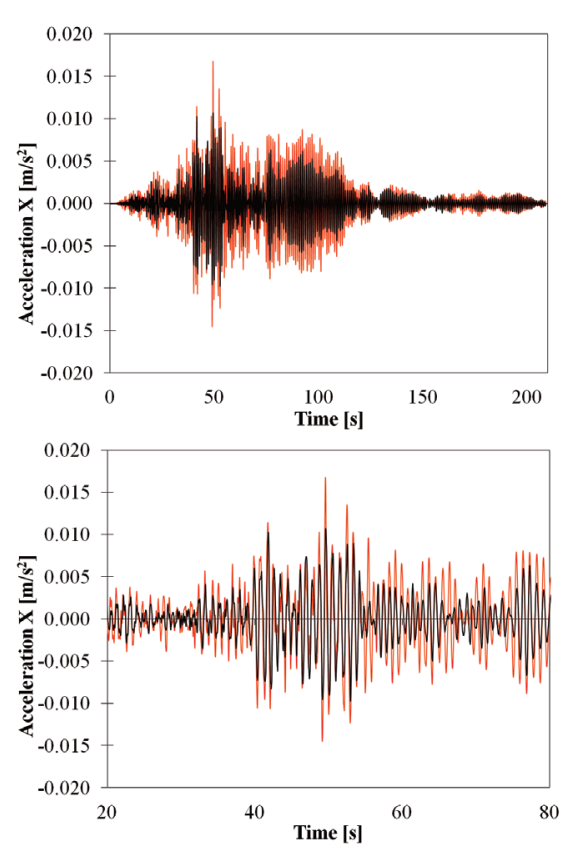

FIGURE 15. Amatrice earthquake. Acceleration in the $\mathrm{X}$ direction at the level of the bell chamber as a function of time $\mathrm{t} \epsilon[0,200]$, experimental in red and numerical in black. Zoom in the interval $[20,80]$ (bottom). 


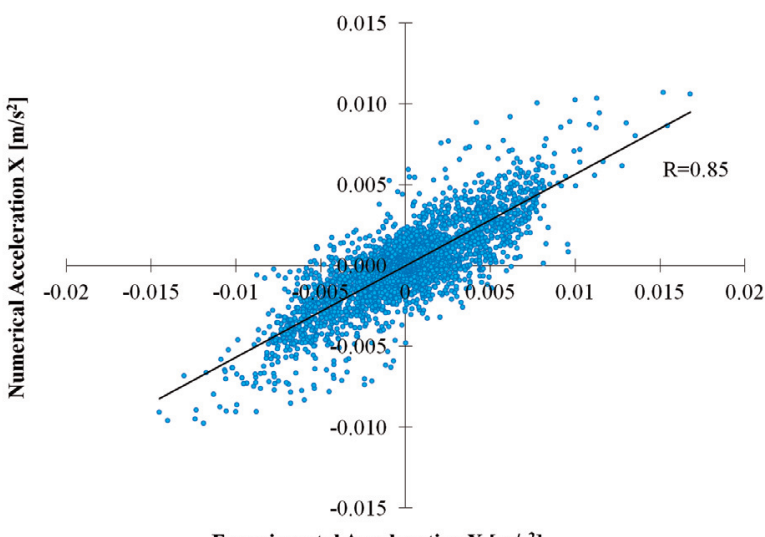

Experimental Acceleration X $\left[\mathrm{m} / \mathrm{s}^{2}\right]$

FIGURE 16. Amatrice earthquake. Numerical vs. experimental accelerations in the $\mathrm{X}$ direction at the level of the bell chamber with their regression line.

in $\mathrm{X}$ direction vs. the corresponding experimental ones.

The regression line is also plotted in the graph: the correlation between the two datasets is quite linear, as demonstrated by the high value of the correlation coefficient. The slope of the regression line, however, indicates that on average the numerical response underestimates the actual accelerations recorded on the tower. Figures 17 and 18 show the tower's response along the $\mathrm{Y}$ direction. The correlation coefficient in Figure 18 is 0.96 , and the slope of the regression line is
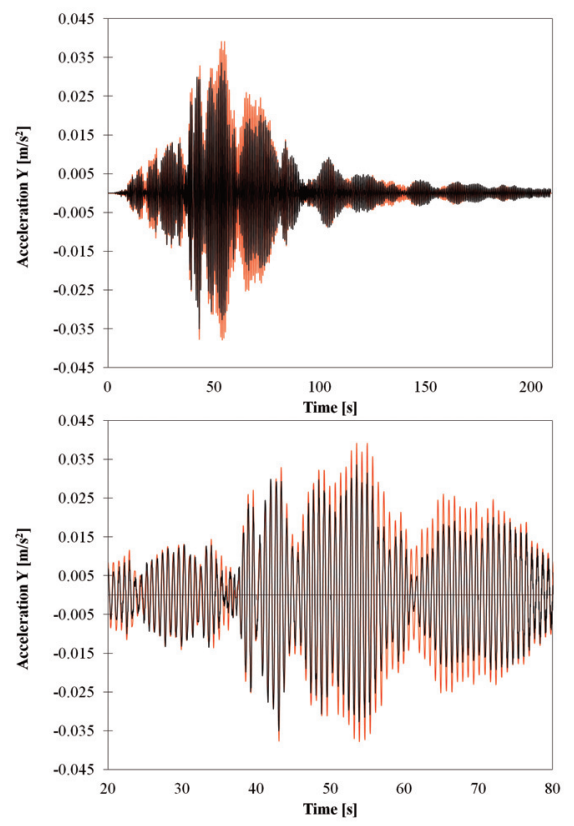

FIGURE 17. Amatrice earthquake. Acceleration in the Y direction at the level of the bell chamber as a function of time $t \in[0,200]$, experimental in red and numerical in black. Zoom in the interval $[20,80]$ (bottom).

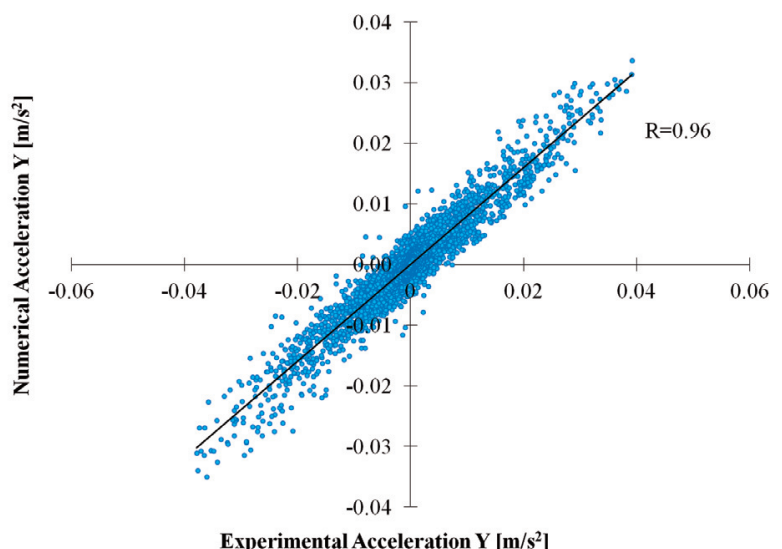

FIGURE 18. Amatrice earthquake. Numerical vs. experimental accelerations in the $\mathrm{Y}$ direction at the level of the bell chamber with their regression line.

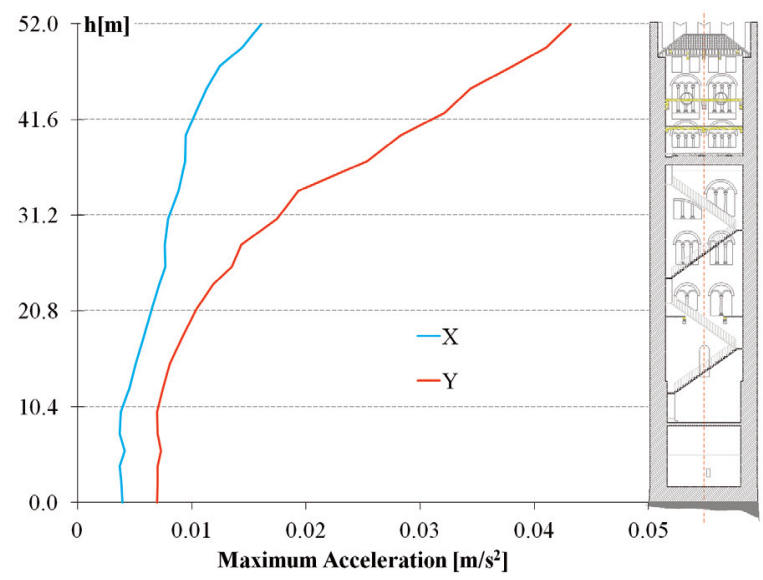

FIGURE 19. Amatrice earthquake. Numerical simulation: Maximum acceleration in the X (cyan) and Y (red) direction vs. height $h$, southern façade.

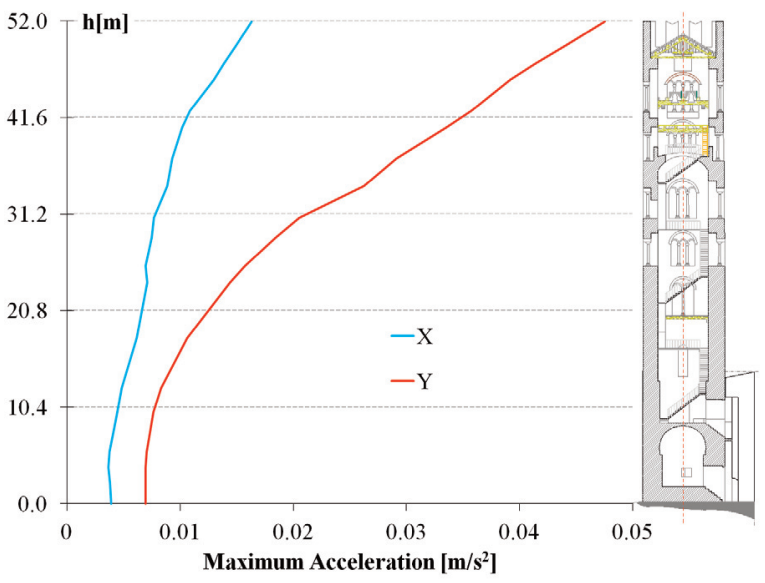

FIGURE 20. Amatrice earthquake. Maximum acceleration in the $\mathrm{X}$ (cyan) and $\mathrm{Y}$ (red) direction vs. height h, eastern façade. 
near 1 , indicating a very good correspondence between the numerical and experimental data, which is also evident by the superposition of the time-histories. Figures 19 and 20 show the acceleration envelopes calculated along the tower's height in the horizontal directions, respectively for the southern and the eastern façade of the tower. The tower exhibits a rather linear amplification of the acceleration values in the $\mathrm{X}$ direction, while amplification along $\mathrm{Y}$ is nonlinear, and despite the low values of the PGA applied at the base, the maximum acceleration at the tower top reaches about five times the value at the base: this finding is in good agreement with the experimental evidence. Table 4 summarizes the maximum acceleration values actually recorded by the instruments at the top and those evaluated numerically via the NOSA-ITACA code. Also in this case, the agreement between the experimental response and the numerical simulation is very good in the $\mathrm{Y}$ direction, while the numerical model seems to underestimate the response along $\mathrm{X}$.

\begin{tabular}{llll} 
& $a_{\text {exp }}\left[\mathrm{m} / \mathrm{s}^{2}\right]$ & $a_{\text {num }}\left[\mathrm{m} / \mathrm{s}^{2}\right]$ & $\Delta a[\%]$ \\
$\mathrm{X}$ & $1.6810^{-2}$ & $1.0710^{-2}$ & $36.3 \%$ \\
$\mathrm{Y}$ & $3.9210^{-2}$ & $3.5010^{-2}$ & $10.71 \%$ \\
\hline
\end{tabular}

TABLE 4. Amatrice earthquake. Maximum accelerations recorded (exp) and calculated (num) at the level of the bell chamber $(+42 \mathrm{~m})$ during the seismic event in the horizontal directions.

\subsection{NUMERICAL DYNAMIC ANALYSIS: RECORD OF THE FIVIZZANO EARTHQUAKE}

The comparison between the numerical and experimental dynamic responses of the San Frediano bell tower shown in the previous subsection furnishes a validation of the tower's FE model under ambient vibrations, including far-field earthquakes. In order to investigate the effects of larger amplitude seismic events, the model has been subjected to the accelerogram recorded at 10:33 a.m. (UTC) in the town of Fivizzano by the FIVI seismic station [Luzi et al., 2017], (itaca.mi.ingv.it) during the earthquake of 21 June 2013. Fivizzano is about $50 \mathrm{~km}$ from Lucca, in the area known as the Lunigiana and the effects of the seismic sequence were clearly felt in the city's historic centre.

The acceleration recorded by the FIVI station is shown in Figure 21, for the North-South and the EastWest components, respectively. The PGA of the event was $1.38 \mathrm{~m} / \mathrm{s}^{2}$, in the North-South direction. The am-
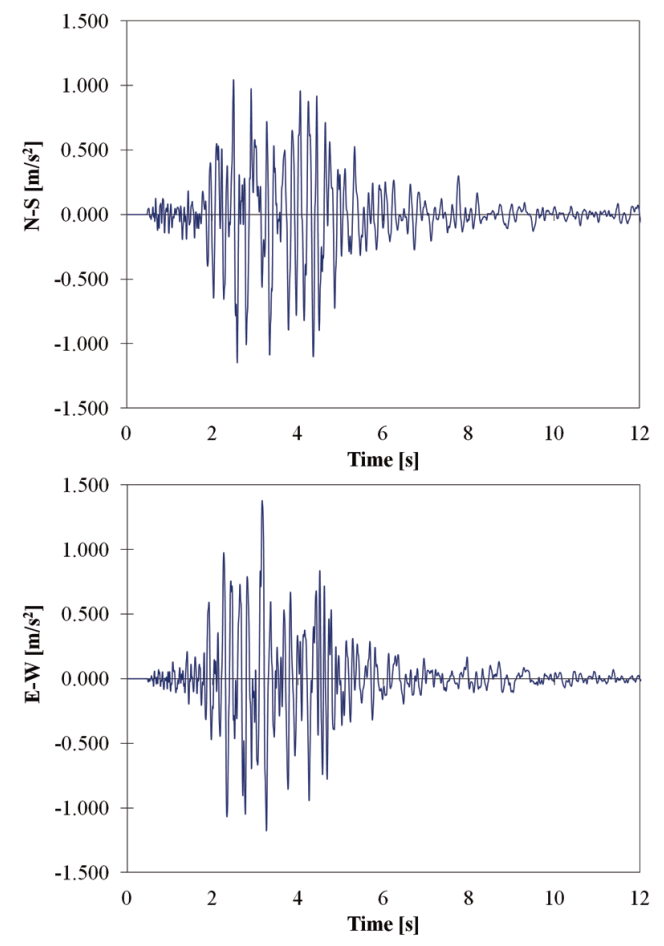

FIGURE 21. Accelerogram of the Fivizzano earthquake (21 June 2013) by the FIVI station, in the North-South and East-West (bottom) directions.

plitudes have a similar order of magnitude in the two directions. The duration of the quaking was $12 \mathrm{~s}$, and the time step for numerical integration was $0.005 \mathrm{~s}$.
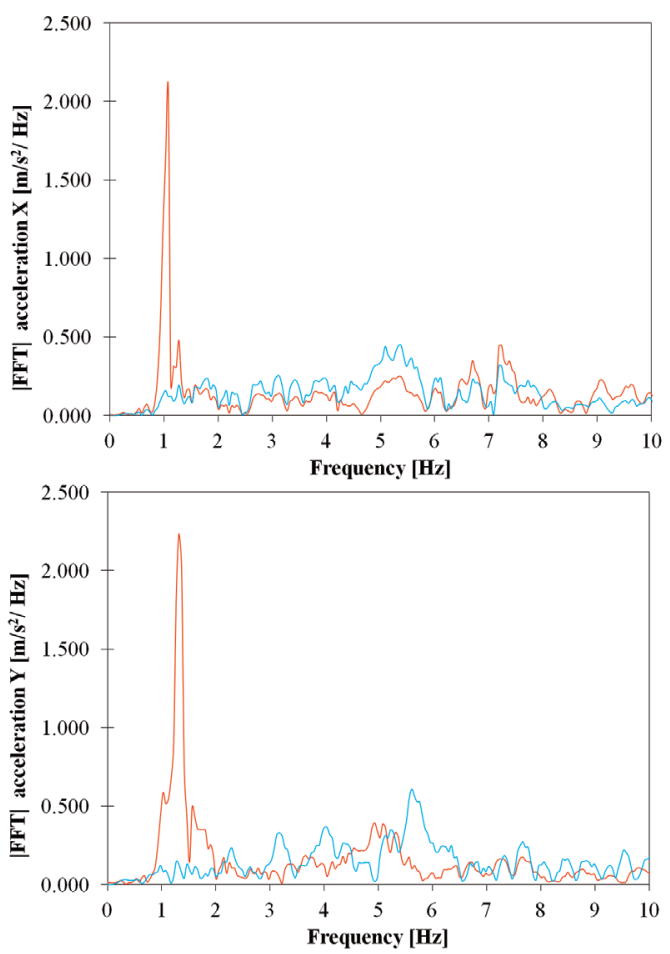

FIGURE 22. Fivizzano earthquake. FFT of the acceleration in the $\mathrm{X}$ and $\mathrm{Y}$ directions at the base (cyan) and at the level of the bell chamber (red). 
After application of the dead loads, the tower model was subected to the Fivizzano earthquake, considering the two directions of the accelerogram simultaneously.

Figures from 22 onward show some results of the dynamic analysis. In particular, Figure 22 shows the FFT of the acceleration at the base and at the top of the tower, in the two horizontal directions. With respect to the Amatrice signal recorded at the tower's base (Figures 11, 12), the spectrum of the Fivizzano earthquake shows high-frequency content. The natural frequencies of the tower are highlighted by the tower's response.

Figure 23 shows the maximum acceleration (with respect to time) computed by NOSA-ITACA vs. the tower's height, along directions $\mathrm{X}$ (cyan) and $\mathrm{Y}$ (red). It is worth noting that the diagrams' shapes are not linear or monotonically increasing with the tower's height, as for the Amatrice earthquake (see Figures 19 and 20), but rather similar to a combination of the structure's highest mode shapes. Strong amplification of the ground accelerations appears in correspondence with the bell chamber. The maximum amplification is however similar to that observed for the Amatrice recording: accelerations at the top are about 5 times those at the ground. With regard to the maximum displacements calculated along the tower's height, Figures 24 and 25 show these quantities evaluated in the middle (red dashed line) of the northern and western façade, respectively. The values reached at the top of the tower are modest in comparison to the tower's height, in agreement with the modest value of the peak ground acceleration, and irregularities in the diagrams are due to the presence of the openings along the façades.

The overall behaviour of the tower, with particular regard to the $\mathrm{X}$ direction, clearly enters the nonlinear field. This is confirmed by Figure 26, where the stress field $\sigma_{\mathrm{zz}}$ at $3.16 \mathrm{~s}$ is plotted, and reveals a significant number of points at which the maximum compressive strength is reached, particularly the portions of masonry within the openings (corresponding to base and top of the pillars between the bifora and trifora windows). High values of compressive strength are also evident at the corners of the base section. Figure 27 shows a plot of the maximum eigenvalue of the crushing strain at $\mathbf{E}^{c}$ $3.16 \mathrm{~s}$. A time-history of the same quantity calculated at point $\mathrm{A}$ is instead plotted for the external (black) and the internal (red) layers in Figure 28. Fracture strains are depicted in Figure 29, where the maximum eigenvalue of the fracture strain $\mathbf{E}^{f}$ is plotted at $3.01 \mathrm{~s}$, for both the external and internal layer. Fracture strains are visible in the spandrels of the windowed façades, giving rise to diagonal cracks, in the tower's upper vault and the highest part of the structure.

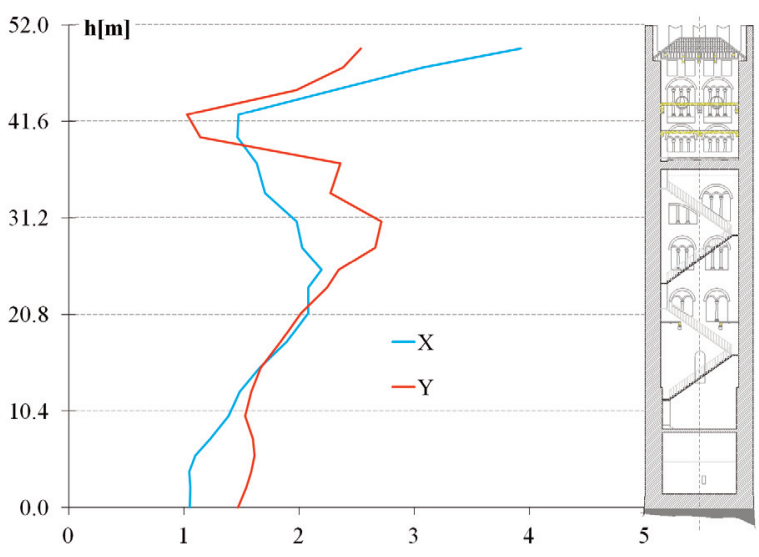

FIGURE 23. Fivizzano earthquake. Maximum acceleration $\left[\mathrm{m} / \mathrm{s}^{2}\right]$ in the X (cyan) and Y (red) directions of the tower's northern fa-çade.

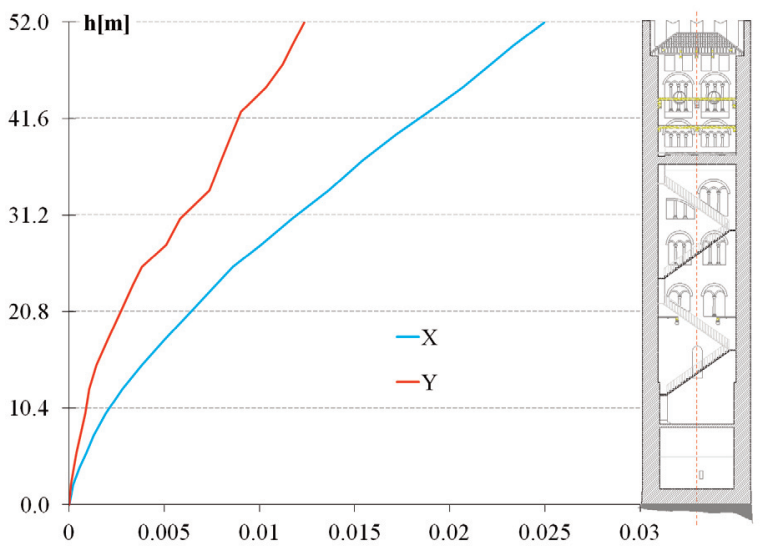

FIGURE 24. Fivizzano earthquake. Maximum displacements [m] in the X (cyan) and Y (red) directions of the tower's northern façade.

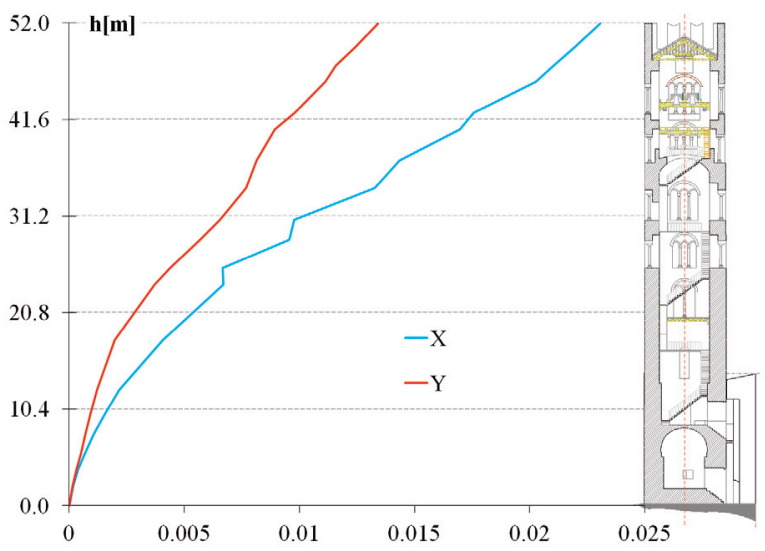

FIGURE 25. Fivizzano earthquake. Maximum displacements [m] in the X (cyan) and Y (red) directions of the tower's western façade. 


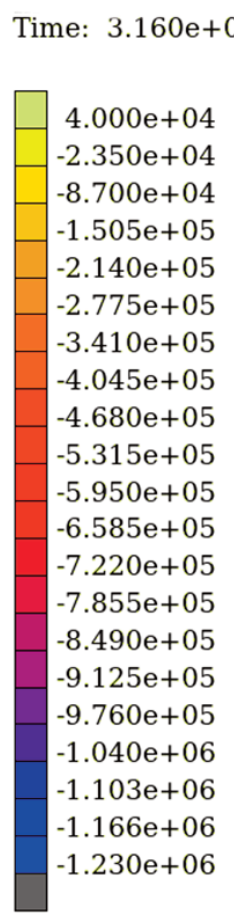

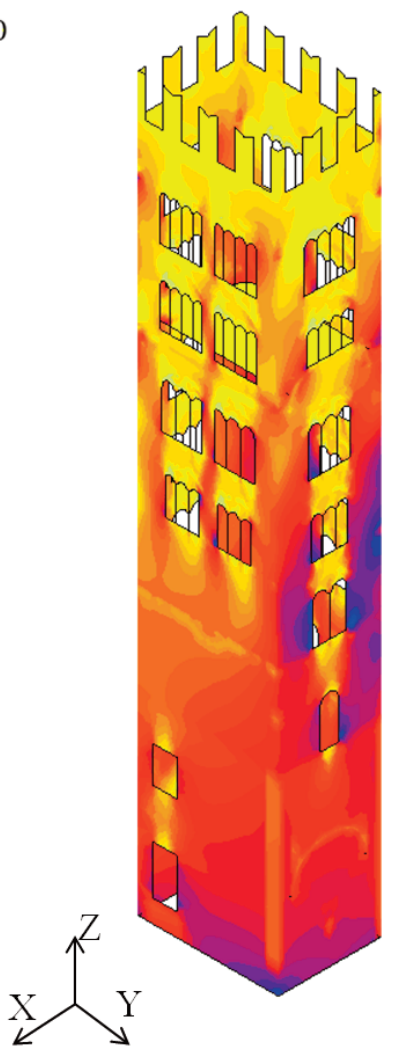
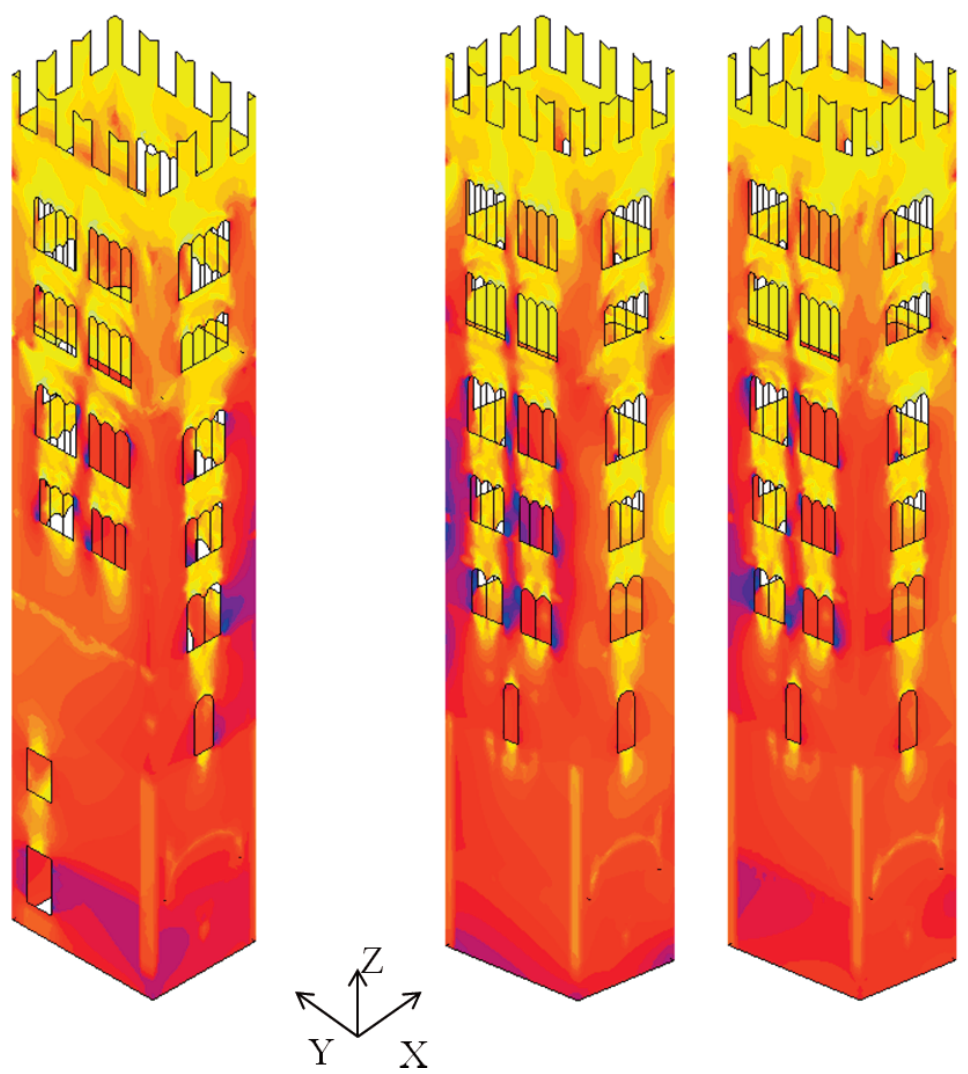

FIGURE 26. Compressive stresses $\sigma_{\mathrm{zz}}[\mathrm{Pa}]$ in the tower at $3.16 \mathrm{~s}$. From the left: $\mathrm{N}-\mathrm{W}$ façade (extrados, intrados), S-E façade (extrados, intrados).

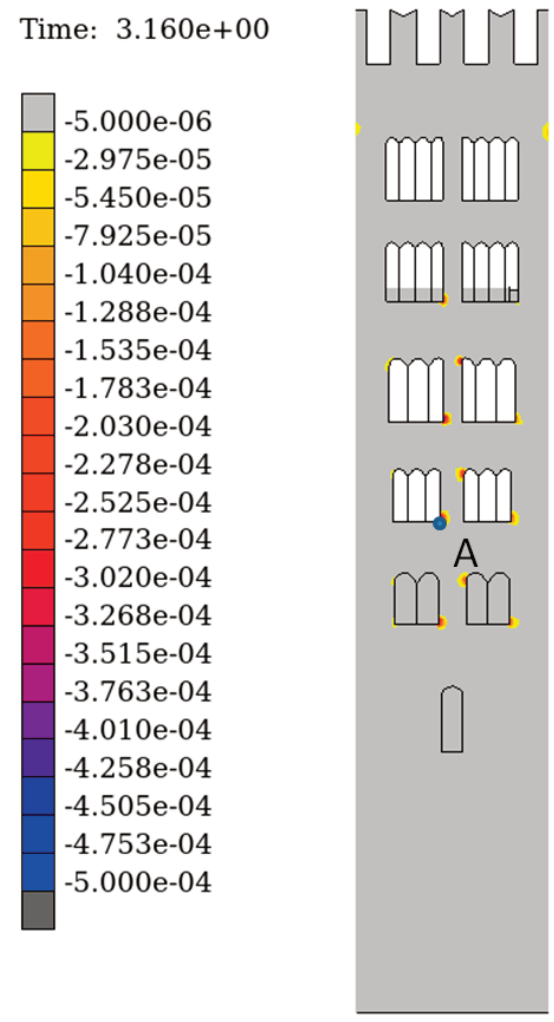

FIGURE 27. Fivizzano earthquake. Minimum eigenvalues of the crushing strain tensor at $3.16 \mathrm{~s}$ in the southern façade.
Figures 30, 31, 32 show the behaviour of the tower's merlons during the seismic event. Under the hypothesis of a rigid body mechanism, the collapse acceleration of the tower's merlons is about $0.34 \mathrm{~g}$ (thickness/height). This value is fully exceeded by the acceleration computed in the merlons, shown in Figure 32, thereby confirming the high vulnerability of the upper part of the

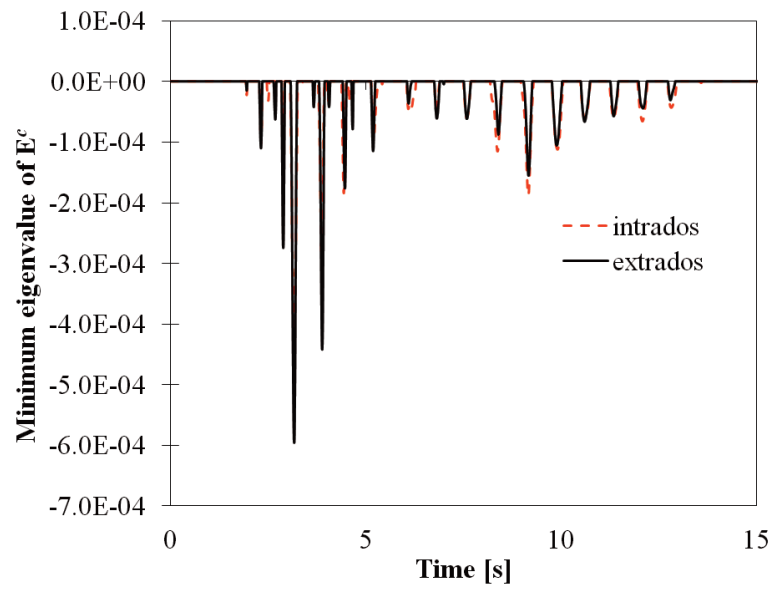

FIGURE 28. Fivizzano earthquake. Time history of the minimum eigenvalue of the crushing strain tensor at point A. Intrados (red) and extrados (black). 

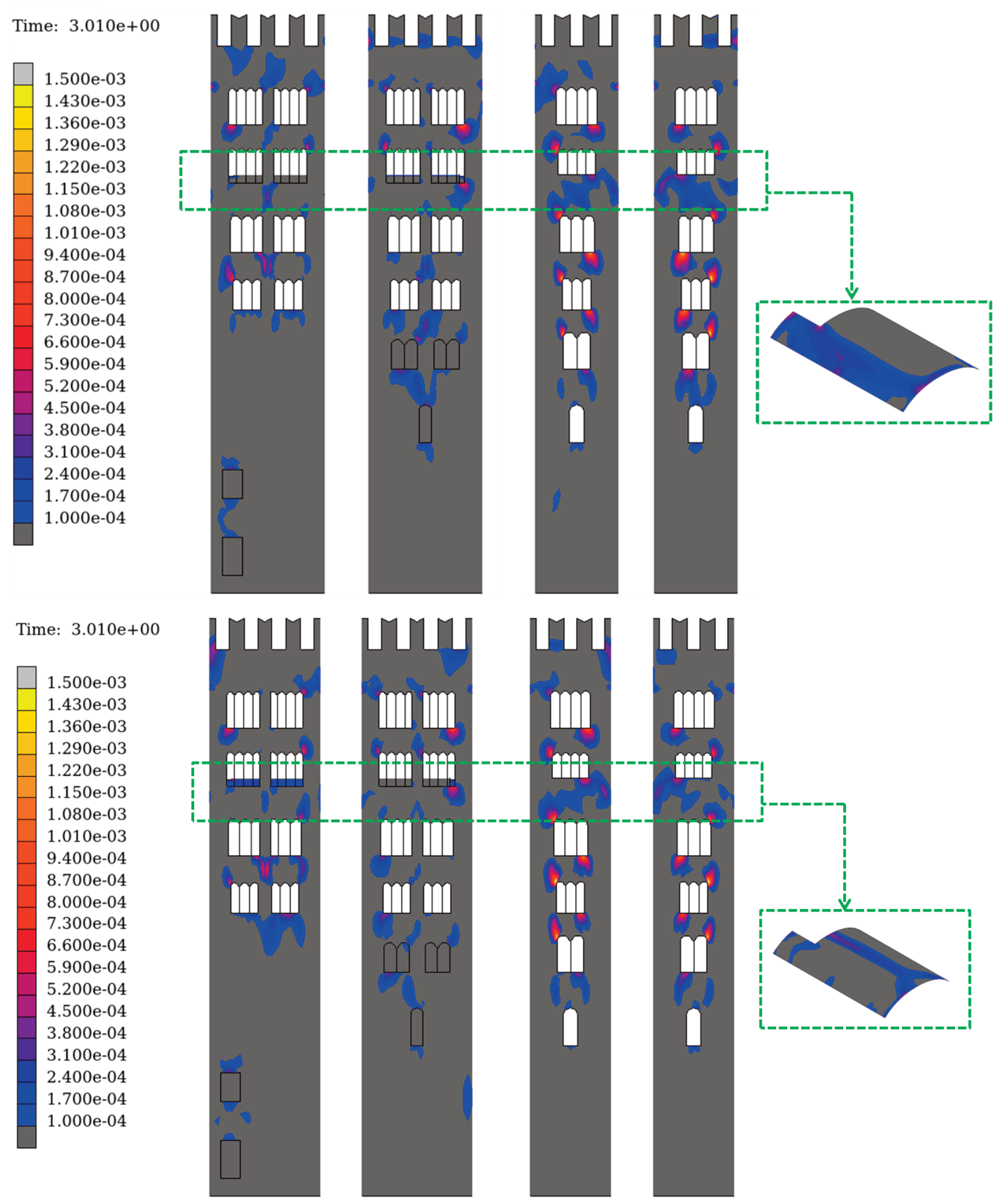

FIGURE 29. Fivizzano earthquake. Maximum eigenvalues of the fracture strain tensor in the tower at $3.01 \mathrm{~s}$ : intrados (bottom) and extrados (up).

tower, which is also in very poor state of maintenance.

In conclusion, despite satisfactory global behaviour of the tower under the seismic event, the numerical simulation reveals local damage concentrated near the openings in the façades and in the vaults, and the high values of the accelerations affecting the upper part of the tower (bell chamber and merlons), which appears to be the most vulnerable to seismic actions. 


$$
\begin{array}{|l}
6.000 \mathrm{e}-04 \\
5.750 \mathrm{e}-04 \\
5.500 \mathrm{e}-04 \\
5.250 \mathrm{e}-04 \\
5.000 \mathrm{e}-04 \\
4.750 \mathrm{e}-04 \\
4.500 \mathrm{e}-04 \\
4.250 \mathrm{e}-04 \\
4.000 \mathrm{e}-04 \\
3.750 \mathrm{e}-04 \\
3.500 \mathrm{e}-04 \\
3.250 \mathrm{e}-04 \\
3.000 \mathrm{e}-04 \\
2.750 \mathrm{e}-04 \\
2.500 \mathrm{e}-04 \\
2.250 \mathrm{e}-04 \\
2.00 \mathrm{e}-04 \\
1.750 \mathrm{e}-04 \\
1.500 \mathrm{e}-04 \\
1.250 \mathrm{e}-04 \\
1.000 \mathrm{e}-04
\end{array}
$$

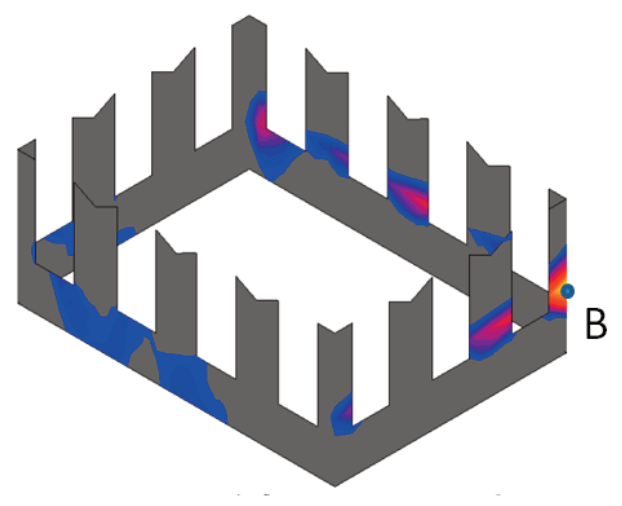

FIGURE 30. Fivizzano earthquake. Maximum eigenvalues of the fracture strain tensor at $2.46 \mathrm{~s}$.

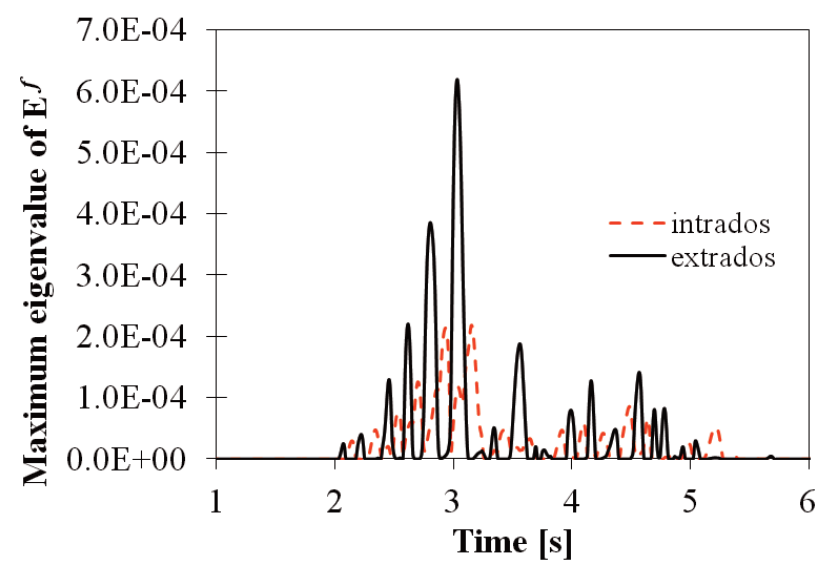

FIGURE 31. Fivizzano earthquake. Maximum eigenvalue of the fracture strain tensor at point B: time history.

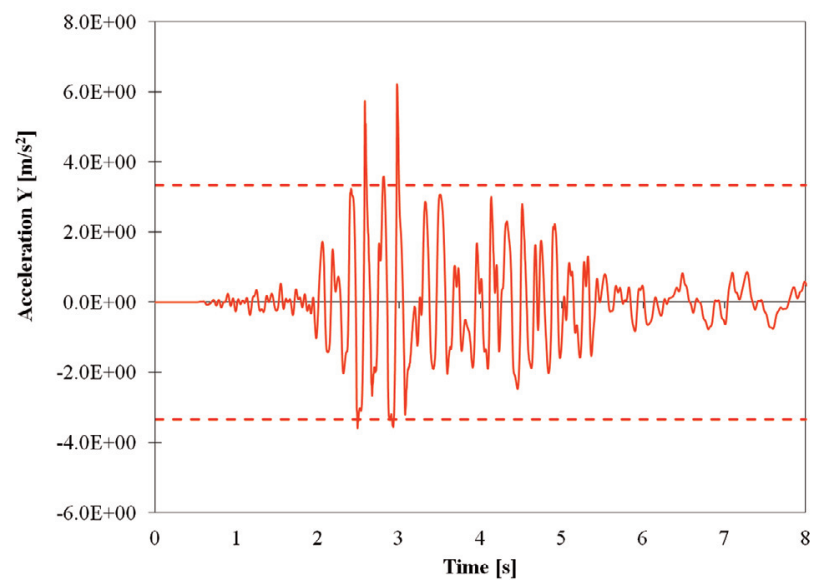

FIGURE 32. Fivizzano earthquake. Acceleration along $\mathrm{Y}$ in a merlon on the West façade: time history.

\section{CONCLUSIONS}

This paper presents a detailed study on the seismic response of the San Frediano bell tower in Lucca, whose ambient vibrations were continuously monitored for about one year by the authors. The novelty of the paper relies on the twofold exploitation of the experimental data recorded on the tower. On the one hand, the experimental results allowed building a realistic FE model of the tower via model updating procedures, on the other, the availability of the tower's experimental response to natural earthquakes, such as the Amatrice earthquake, allowed performing and validating the dynamic simulations conducted via the FE code NOSAITACA. Lastly, the tower's response to the Fivizzano earthquake was simulated and analyzed, pointing out the sensitivity of the tower to such an excitation. The paper emphasizes the importance of both experimental measurements and numerical simulations in assessing the seismic behaviour of historic masonry buildings.

\section{REFERENCES}

Acito M., M. Bocciarelli, C. Chesi and G. Milani (2014). Collapse of the clock tower in Finale Emilia after the May 2012 Emilia Romagna earthquake sequence: Numerical insight. Engineering Structures, 72, 70-91.

Azzara R.M., L. Zaccarelli A. Morelli., T. Trombetti G. Dallavalle, A. Cavaliere and S. Danesi (2014). Seismic monitoring of the Asinelli and Garisenda medioeval towers in Bologna (Italy), an instrumental contribution to the engineering modeling direct to their protection. In F. M. Mazzolani \& G. Altay (eds.), Proceedings of the second International Conference on Protection of Historical Constructions (PROHITECH 2014). Proc. intern. symp., Antalya, Turkey, May 7-9 2014. Istanbul: Boğaziçi University Publishing.

Azzara R.M., G. De Roeck, M. Girardi, C. Padovani, D. Pellegrini and E. Reynders (2016). Assessment of the dynamic behaviour of an ancient masonry tower in Lucca via ambient vibrations. Van Balen Koen, Verstrynge Els, editors. Structural analysis of historical constructions. anamnesis, diagnosis, therapy, controls, Taylor \& Francis Group, 2016, Print ISBN: 978-1-138-02951-4 eBook ISBN: 978-1317-20662-0.

Azzara R. M., G. De Roeck, M. Girardi., C. Padovani, D. Pellegrini and E. Reynders (2018). The influence of environmental parameters on the dynamic be- 
haviour of the San Frediano bell tower in Lucca. Engineering Structures, 156, 175-187.

Barsocchi P., P. Cassara, F. Mavilia and D. Pellegrini (2018). Sensing a City's State of Health: Structural Monitoring System by Internet-of-Things Wireless Sensing Devices. IEEE Consumer Electronics Magazine, 7(2), 22-31.

Bartoli G., M. Betti and S. Giordano (2013). In situ static and dynamic investigations on the "Torre Grossa” masonry tower. Engineering Structures, 52, 718-733.

Bartoli G., M. Betti, P. Biagini, A. Borghini, A. Ciavattone, M. Girardi, G. Lancioni, A.M. Marra, B. Ortolani, B. Pintucchi and L. Salvatori (2017). Epistemic uncertainties in structural modeling: a blind benchmark for seismic assessment of slender masonry towers. Journal of Performance of Constructed Facilities 31(5), ASCE:

Bayraktar A., A. Şahin, D. M. Özcan and F. Yildirim, (2010). Numerical damage assessment of Haghia Sophia bell tower by nonlinear FE modeling. Applied Mathematical Modelling, 34(1), 92-121.

Bernardeschi K., C. Padovani and G. Pasquinelli (2004). Numerical modelling of the structural behaviour of Buti's bell tower. Journal of Cultural Heritage, 5(4), 371-378.

Binante V., M. Girardi, C. Padovani, G. Pasquinelli, D. Pellegrini, M. Porcelli and L. Robol (2017). NOSA-ITACA 1.1, cnr.isti/2017-SW-013, www.nosaitaca.it. Bocciarelli M., and G. Barbieri (2017). A numerical procedure for the pushover analysis of masonry towers. Soil Dynamics and Earthquake Engineering, 93, 162-171.

Brincker R., and C. Ventura (2015). Introduction to Operational Modal analysis, Wiley.

Cakir F., E. Uckan, J. Shen, S. Seker and B. Akbas (2016). Seismic performance evaluation of slender masonry towers: a case study. The Structural Design of Tall And Special Buildings, 25(4), 193-212.

Callieri M., M. Corsini, M. Girardi, A. Pagni, C. Padovani, G. Pasquinelli and R. Scopigno, (2010). The Rognosa tower in San Gimignano: Digital acquisition and structural analysis. Proceedings of the Tenth International Conference on Computational Structures Technology, Civil-Comp Press.

Casolo S., (1998). A three-dimensional model for vulnerability analysis of slender medieval masonry towers. Journal of Earthquake Engineering, 2(4), 487-512.

Casolo S., G. Milani, G. Uva and C. Alessandri (2013). Comparative seismic vulnerability analysis on ten masonry towers in the coastal Po Valley in Italy. En- gineering Structures, 49, 465-490.

Castellazzi G., A. M. D’Altri, S. de Miranda, A. Chiozzi and A. Tralli (2018). Numerical insights on the seismic behavior of a non-isolated historical masonry tower. Bulletin of Earthquake Engineering, 16(2), 933-961.

Cattari S., S. Degli Abbati, D. Ferretti, S. Lagomarsino, D. Ottonelli and A.Tralli (2014). Damage assessment of fortresses after the 2012 Emilia earthquake (Italy), Bulletin of Earthquake Engineering, 12: 2333. https://doi.org/10.1007/s10518-013-9520-x.

Clough R.W. and Penzien J., (1975). Dynamics of Structures, Mc-Grow Hill, Inc.

D’Altri A. M., G. Castellazzi and S. de Miranda (2018). Collapse investigation of the Arquata del Tronto medieval fortress after the 2016 Central Italy seismic sequence. Journal of Building Engineering, 18, 245-251.

D’Ambrisi A., V. Mariani and M. Mezzi (2012). Seismic assessment of a historical masonry tower with nonlinear static and dynamic analyses tuned on ambient vibration tests. Engineering Structures, 36, 210-219.

De Falco A., M. Girardi and D. Pellegrini (2014). NonLinear Analyses on the Medieval "Ponte del Diavolo" in Borgo a Mozzano (Italy). In B.H.V. Topping and P. Iványi, (eds), Twelfth International Conference on Computational Structures Technology; Proc. intern. symp., Civil-Comp Press.

Degl'Innocenti S., C. Padovani and G. Pasquinelli (2006) Numerical methods for the dynamic analysis of masonry structures, Structural Engineering and Mechanics, 22(1), 107-130.

Del Piero G., (1989). Constitutive equation and compatibility of the external loads for linearly-elastic masonry-like materials. Meccanica, 24 pp.150-162.

Di Pasquale S., (1992). New trends in the analysis of masonry structures. Meccanica, 27, pp. 173-184.

D.M. 2018. Aggiornamento delle Norme Tecniche per le Costruzioni, 17 gennaio 2018, G.U. 20 febbraio 2018, n. 42.

D.P.C.M. 2011. Direttiva del Presidente del Consiglio dei Ministri del 9 febbraio 2011: Valutazione e riduzione del rischio sismico del patrimonio culturale con riferimento alle Norme Tecniche per le Costruzioni di cui al D. M. 14 gennaio 2008. G.U. n. 47 del 26 febbraio 2011- Suppl. ord. N. 54.

de Silva F., Pitilakis D., Ceroni F., Sica S., \& Silvestri F., 2018. Experimental and numerical dynamic identification of a historic masonry bell tower accounting for different types of interaction. Soil Dynamics and Earthquake Engineering, 109, 235-250. 
De Stefano A., E. Matta and P. Clemente (2016). Structural health monitoring of historical heritage in Italy: some relevant experiences, Journal of Civil Structural Health Monitoring, 6(1), 83-106, https://doi.org/10.1007/s13349-016-0154-y.

Ferraioli M., L. Miccoli, D. Abruzzese. and A. Mandara (2017). Dynamic characterisation and seismic assessment of medieval masonry towers. Natural Hazards, 86(2), 489-515.

Gentile C. and A. Saisi (2007). Ambient vibration testing of historic masonry towers for structural identification and damage assessment. Construction and building materials, 21(6), 1311-1321.

Girardi, M., C. Padovani, and D. Pellegrini (2015). The NOSA-ITACA code for the safety assessment of ancient constructions: a case study in Livorno. Adv Eng Software, 89; 64-76.

Girardi, M., C. Padovani and D. Pellegrini, (2018). Modal analysis of masonry structures. Mathematics and Mechanics of Solids, 1081286517751837.

Júlio E. N. B. S., C. A. da Silva Rebelo and D.A.S.G. Diasda Costa (2008). Structural assessment of the tower of the University of Coimbra by modal identification. Engineering Structures, 30(12), 34683477.

Karanikoloudis G. and P.B. Lourenço. (2018). Structural assessment and seismic vulnerability of earthen historic structures. Application of sophisticated numerical and simple analytical models. Engineering Structures, 160, 488-509.

Lourenco P.B., N. Mendes, R. Marques, 2009. Earthquake Design and Assessment of Masonry Structures: Review and Applications. In Trends in Civil and Structural Engineering Computing, Topping B.H.V., Costa Neves L.F., Bar-ros R.C. Eds, Saxe Coburg Publications.

Lucchesi M., C. Padovani and A. Pagni (1994). A numerical method for solving equilibrium problems of masonry-like solids. Meccanica, 29(2), 175-193.

Lucchesi M. and B. Pintucchi (2007). A numerical model for non-linear dynamic analysis of slender masonry structures. European Journal of Mechanics A/Solids, 26, 88-105.

Lucchesi M., C. Padovani, G. Pasquinelli. and N. Zani (2008). Masonry constructions: mechanical models and numerical applications. Lecture Notes in Applied and Computational Mechanics, 39. Berlin, Springer-Verlag.

Luzi L., F. Pacor, R. Puglia (2017). Italian Accelerometric Archive v 2.3. Istituto Nazionale di Geofisica e Vulcanologia, Dipartimento della Protezione Civile Nazionale. doi: 10.13127/ITACA.2.3.
Masciotta M.G., L.F. Ramos, P.B. Lourenço and M. Vasta (2017). Damage Identification and Seismic Vulnerability Assessment of a Historic Masonry Chimney. Annals of Geophysics, 60(4), 0442.

Milani G., S. Casolo, A. Naliato and A. Tralli (2012). Seismic assessment of a medieval masonry tower in Northern Italy by limit, nonlinear static, and full dynamic analyses. International Journal of Architectural Heritage, 6(5), 489-524.

Minghini F., G. Milani and A. Tralli (2014). Seismic risk assessment of a $50 \mathrm{~m}$ high masonry chimney using advanced analysis techniques. Engineering Structures, 69, 255-270.

Padovani C., G. Pasquinelli and M. Šilhavý (2008). Processes in masonry bodies and the dynamical significance of collapse, Mathematics and Mechanics of Solids, 13, 573-610.

Pellegrini D., M. Girardi, P.B. Lourenço, M.G. Masciotta, N. Mendes, C. Padovani and L.F. Ramos (2018). Modal analysis of historical masonry structures: Linear perturbation and software benchmarking. Construction and Building Materials, 189, 1232-1250.

Pineda Palomo P., M.A. Gil Marti and M.D. Robador González (2011). Seismic damage propagation prediction in ancient masonry structures: an application in the non-linear range via numerical models. Open Construction \& Building Technology Journal, 1-15.

Porcelli M., V. Binante, M. Girardi, C. Padovani, G. Pasquinelli (2015). A solution procedure for constrained eigenvalue problems and its application within the structural finite element code NOSA-ITACA. Calcolo, 52:2, 167-186.

Preciado A., (2015). Seismic vulnerability and failure modes simulation of ancient masonry towers by validated virtual finite element models. Engineering Failure Analysis, 57, 72-87.

Resta M., A. Fiore and P. Monaco (2013). Non-linear finite element analysis of masonry towers by adopting the damage plasticity constitutive model. Advances in Structural Engineering, 16(5), 791-803.

Reynders E., M. Schevenels. and G. De Roeck (2014). MACEC 3.3. A Matlab toolbox for experimental and opera-tional modal analysis. http://bwk.kuleuven.be/bwm/macec/.

Reynders E., Maes K., G. Lombaert and G. De Roeck (2016). Uncertainty quantification in operational modal analysis with stochastic subspace identification: Validation and applications. Mech. Syst. Signal Process 66-67:13-30.

Sabia D., T. Aoki, R. M. Cosentini and R. Lancellotta (2015). Model updating to forecast the dynamic behavior 
of the Ghirlandina Tower in Modena, Italy. Journal of Earthquake Engineering, 19(1), 1-24.

Shakya M., H. Varum, R. Vicente and A. Costa (2018). Seismic vulnerability assessment methodology for slender masonry structures. International Journal of Architectural Heritage, 1-30.

Ubertini F., N. Cavalagli, A. Kita and G. Comanducci (2018). Assessment of a monumental masonry bell-tower after 2016 Central Italy seismic sequence by longterm SHM. Bulletin of Earthquake Engineering, 16(2), 775-801.

Valente M. and G. Milani (2016a). Non-linear dynamic and static analyses on eight historical masonry towers in the North-East of Italy. Engineering Structures, 114, 241-270.

Valente M. and G. Milani (2016b). Seismic assessment of historical masonry towers by means of simplified approaches and standard FEM. Construction and Building Materials, 108, 74-104.

Zanotti Fragonara L., G. Boscato, R. Ceravolo, S. Russo, S. Ientile, M.L. Pecorelli and A. Quattrone (2017). Dynamic investigation on the Mirandola bell tower in post-earthquake scenarios. Bulletin of Earthquake Engineering, 15(1), 313-337.

"CORRESPONDING AUTHOR: Maria GIRARDI,

Institute of Information Science and Technologies "A. Faedo",

ISTI-CNR, Pisa, Italy

email: maria.girardi@isti.cnr.it

(c) 2019 the Istituto Nazionale di Geofisica e Vulcanologia.

All rights reserved 